\title{
Interrogating the importance and awareness of NSS improvement initiatives: A case study of final year undergraduate students
}

\begin{abstract}
This paper reports the results of a case study investigating the importance and awareness of national student survey (NSS) improvement initiatives in one department at a university in the South of England. The paper is motivated by the observation that despite many initiatives that the Department put in place since 2011 in response to poor NSS results, the overall students' satisfaction remained below the national average for the period 2011-2015. This situation raises two questions. First, are the initiatives put in place really important for students' satisfaction when it comes to responding to the NSS questionnaire? Second, are the students even aware of these initiatives? To answer these questions, 57 initiatives that the Department put in place from 2011 to 2015 were documented using the minutes of various education committees. Through a questionnaire survey, the final year students in the Department were asked to rate on a 5-point Likert scale the importance and their awareness of the initiatives. Descriptive, correlation analysis and t-tests are used to determine the importance and awareness of the initiatives. The data analysis was followed by two focus groups with selected students to gain further insights into the findings. The main results of the study are that many of the 57 initiatives are considered important but the students are not aware of the majority of the initiatives. These results have important implications for UK university departments trying to improve their NSS results.
\end{abstract}

Keywords: Initiatives, importance, awareness, NSS improvement 


\section{Introduction}

The purpose of this paper is to investigate the importance and awareness of the National Students Survey (NSS) improvement initiatives that were put in place by one business school department at a university in the South of England. The initiatives were deemed necessary from 2011, following a 53-point fall in the overall NSS satisfaction rates from $93 \%$ in 2010 to $40 \%$ in 2011. The NSS questionnaire consisted of twenty-two questions which were divided into seven sections. The first twenty-one questions fell under one of six subheadings on: the teaching on my course, assessment and feedback, academic support, organisation and management, learning resources and personal development. The last question was about the overall quality of the course. For each of the twenty-two questions, students were asked to indicate their level of endorsement on a 5-point scale, ranging from definitely disagree to definitely agree.

The NSS results for the Department under study were excellent up until 2011. The significant fall in student satisfaction during the academic year 2010/11 may have largely been attributed to a restructuring within the Department with regard to teaching staff. The Department responded immediately to the significant decline in NSS results in 2011 with the introduction of numerous initiatives aimed at improving responses to specific questions in the NSS questionnaire. For example, to increase satisfaction under the 'teaching on your course' section, the Department introduced a policy of two to four guest lectures at every level, encouraged staff to pursue recognised teaching qualifications and use technology to enhance learning. To improve results to the NSS questions under 'assessment and feedback', the Department introduced a standardised feedback form, conducted internal audits of feedback to ensure good quality and encouraged electronic marking among other initiatives. To elicit more positive responses to questions under the 'academic support' section of the NSS questionnaire, 
staff were encouraged and expected to respond to student emails within two days, a student charter was published and each student was assigned an academic advisor.

It must be acknowledged that the NSS results for the Department bounced back by 43 points in 2012 (40\% in 2011 to 88\% in 2012), which may indicate cohort-bias. However, despite the bounce and the continual introduction of numerous initiatives aimed at improving positive responses to the NSS questionnaire, the NSS satisfaction rates of the Department have remained below the national average. This raises the question of why these initiatives have not delivered the desired results. Kovacs, Grant, and Hyland (2010), for example, noted that departments acted on areas of concern in a wide range of ways dependent on resources available, personal approach and areas identified which is exactly what this department did without success. Kovacs, Grant, and Hyland (2010) therefore called for further research to identify the effectiveness of various strategies pursued by different university departments.

This case study therefore partly responds to such calls by investigating the importance of the initiatives and also extends previous studies by examining the awareness of such initiatives in improving NSS results. Specifically, this case study seeks to answer the following research questions: (1) How important are the initiatives to the students when it comes to responding to the NSS? (2) To what extent are the students aware of the initiatives aimed at improving the NSS results? Given that much has been written on student experience, their perceptions on the quality of teaching and a range of university services aimed at fostering their satisfaction (Race 2010; Brown 2011; Ginns, Prosser, and Barrie, 2007; Kane, Williams, and Cappuccini-Ansfield, 2008), this paper brings to the fore a different dimension. By unveiling the interconnection between strategies aimed at improving student satisfaction, the awareness of such strategies and their bearing on the student experience, interventions designed to serve students can be well received and maximised for utmost outcomes. 
The rest of the paper is organised as follows: The next section is the literature review on how universities have sought to improve their NSS questionnaire results and to what extend such efforts have been successful. In Section 3, the research methodology is discussed. This is followed in Section 4 by a discussion of the results. The final section is a summary and conclusion.

\section{Literature review}

The NSS survey is an annual and on-going practice in UK universities, commissioned by the HEFCE (Lenton 2015; Ginns, Prosser, and Barrie 2007; Kane, Williams, and Cappuccini-Ansfield, 2008; Race 2010). It informs university ranking and enrolment choice amongst prospective students as they seek the best value for investment in higher education. However, there is relatively very little published research on what different universities are doing to improve their NSS results given its importance. This is not surprising given that whatever initiative each university comes up with is a source of competitive advantage and therefore remains confidential. For example, Flint et al. (2009) describe the quality enhancement focused response to NSS by Sheffield Hallam University in the UK. Specifically, the research explains what transpired on a day that was dedicated to improving the NSS by bringing together a number of stakeholders including students, staff and senior management. Flint et al. (2009) point out that one of the tangible outputs from the one day meeting was the leaflet entitled 'You Said, We Did...' which was so successful that updated versions were developed and circulated. In addition, Flint et al. (2009) also point out a number of initiatives such as electronic feedback on assessment, building connections between student personal development planning and continuing professional development.

Kovacs, Grant, and Hyland (2010) reported that the universities they surveyed responded to the NSS results through various initiatives. For example, in response to 
dissatisfaction with assessment and feedback, the tutors were asked to embark on electronic marking and the Departments started working closely with the Student Union to clarify marking practices and course information in student and module handbooks. Other initiatives also included giving verbal and detailed feedback to students via voice recording; organising group feedback sessions to provide general and specific guidance; introducing a policy to return assignments within 20 days and organising an assessment and feedback conference. Further, in response to learning resources, some university departments introduced laptop loan scheme and offered an ongoing programme of support for staff and students to make best use of technology.

Race (2010) and Brown (2011) also describe a number of actions that were taken in some institutions to improve the results of the NSS. These actions include among others: zero tolerance on cancellation of classes, mutual expectations document, recruitment of the right staff for teaching; training for new academic staff; peer observation of teaching; feedback on assessed work; changing culture; helping students to take strong ownership of their learning needs and giving students more opportunities to learn by doing. In addition, Flint et al. (2009) also addresses an institution's aspiration and student focused response to the NSS by implementing an innovative approach to dealing with the issues raised by the NSS and this involves capturing and maximising student voice and involving a broader range of colleagues in tackling the issues raised by the NSS amongst others. Brown (2011) reports a significant improvement to the 2010 NSS results following the various actions taken which suggest that the initiatives had a favourable influence; it is however not clear which of the various initiatives had the most influence on the outcome and also to what extent the students were aware of the initiatives. 


\section{Research Methodology}

\subsection{Sample}

The population of the study was the 105 Accounting and Finance Framework students who were in their final year of their degree programmes. A questionnaire survey (see below) was distributed to these students in hard copy. A total of 57 questionnaires were completed, forming the basis of the results discussed in this article. Three final-year students on the framework were recruited to participate in the framing and administration of the questionnaires to their peers, guide discussions, transcribe recordings and participate in the analytical processes. It was assumed that the students' involvement in the project as co-researchers would elicit honest participation and responses from their peers.

\subsection{Identifying the Initiatives}

To identify the initiatives undertaken since 2011, the minutes of various education committees such as framework meetings and student experience forums were considered. The initiatives were summarised each year in a document entitled the Education and Student Experience Plan (ESEP). These documents were analysed noting new initiatives, their original sources, their rationale and their effective dates of implementation. All the initiatives were then grouped under one of the six categories included in the NSS questionnaire (that is, the teaching on my course, assessment and feedback, academic support, organisation and management, learning resources, personal development and overall satisfaction).

\subsection{Questionnaire}

The anonymous survey questionnaire consisted of three sections. Section A asked for information about the background of the respondent such as gender, predicted degree classification based on second year results, whether the student intended to complete the NSS 
survey online and their degree of satisfaction for each of their three or four years at university (which may have included a placement year). As evident in Table 1, the level of satisfaction over the duration the respondents have spent on their course was captured on a single Likert scale from 1 to 5 with 5 being 'very satisfied'. Section B consisted of a list of the initiatives the Department had introduced since 2011 in response to the NSS results. The initiatives were grouped under the first six headings of the NSS questionnaire: the teaching on my course (13 initiatives), assessment and feedback (12), academic support (14), organisation and management (10), learning resources (2) and personal development (6). The students were asked to rate on a 5-point Likert scale the awareness and importance of the initiatives, $1=$ not important (not aware) at all to 5= very important (very aware). The awareness of the initiatives related to the students' prior knowledge since this was the first time the students had ever been asked about such initiatives. Section C consisted of six open-ended, section-specific questions which were meant for students to volunteer any initiative that they had not been asked about in Section B. The relative importance and awareness of the NSS improvement initiatives results from the questionnaire were further explored through two focus groups discussions.

\subsection{Focus Groups}

Given the need to generate more data by probing into the survey results, two focus groups were held. The groups were made up of seven participants of mixed gender, selfselected (Sterba and Foster 2008, Wainer 1986) from a pool of respondents who had taken part in the survey and were willing to be part of a discussion. Focus groups are typically different from one-to-one interviews where the researcher simply asks the interviewee a series of questions. In this case, instead of asking each participant in the focus groups to respond to a question, the researcher encourages participants to contribute ideas to a discussion theme. This method is particularly useful in generating ideas by exploring participants' knowledge and 
experience (Kitzinger 1995, Morgan. 1996). The focus groups occasioned opportunities to obtain richer and more detailed data. The discussions were recorded and later transcribed.

\subsection{Data Analysis}

Descriptive statistics were employed to summarise the results of the background information in Section A and also to calculate the mean for the importance and awareness of the various initiatives in Section B. The initiatives under the six NSS questionnaire categories were then ranked according to the mean. A one-sample t-test was conducted for both the importance and awareness of the initiatives comparing the sample mean to the mid-point (assumed mean) of 3 on the 5-point Likert scale similar to Torres (2004). This was meant to establish each initiative deemed significantly important and also whether the students were significantly aware of each initiative. Correlation analysis was conducted between the importance and awareness of only those initiatives that were found to be significantly important. The ensuing data from the focus groups was analysed thematically (Aronson 1995, Fereday and Muir-Cochrane 2006, Boyatzis, 1998) by two members of the research team. In order to maximise the analytical approach, all transcriptions from recorded interviews were checked properly to ensure consistency and they reflected the views of the participants. Given that there are different ways themes can be identified and sorted out from research data and these include evidences of repetitions, transitions, differences, indigenous typologies and linguistic connectors (Ryan and Bernard 2003), the process was data driven (Wolcott 1994). That is, the members of the research team were not subjected to a predetermined theory or any form of bias but took the voices of focus group participants at face value irrespective of similar or contrary views expressed. The participants' views have been captured in the following discussion that follows, 


\section{Results and Discussion}

\subsection{Nature of the Respondents}

The background information for the respondents to the questionnaire (see Appendix 1, Section A) is summarised in Table 1. The results indicate that females constituted $59.60 \%$ of the sample compared to $40.40 \%$ males. The results also show that the majority of the respondents were working towards a 2.1 degree classification $(70.18 \%)$ and only $5 \%$ thought that they would be able to achieve a first class degree. As expected, a very high percentage of the students $(94.74 \%)$ were aware of the NSS. However, while $75 \%$ of the respondents stated that they would or had already completed the NSS survey, the remaining $24.56 \%$ (14 students) did not intend to complete the survey. Ten of the fourteen students (over 70\%) that said they did not want to complete the NSS were male which may suggest that this category is less likely to complete the questionnaire compared to the female category.

\section{[Table 1 ABOUT HERE]}

The examination of the reasons proffered by the fourteen students suggest that seven students believed that their completion of the questionnaire would not make a difference, while four stated that there was no incentive for them to do so and another three students said that the questionnaire was too long. In terms of levels of satisfaction, the results show that the students were more satisfied during their placement year with a mean rating of 4.27 , followed by the first year (3.74), final year (3.72) and finally the second year (3.63). The satisfaction during the placement year could be due to the students' abilities to apply their learned skills and knowledge in the work place and receive remuneration. 


\subsection{Importance and Awareness of the Initiatives}

\subsubsection{Teaching on Your Course}

The initiatives that were taken to improve results to Section A 'teaching on your course' of the NSS questionnaire are in Table 2, Panel A. Ranking on the basis of the mean, the results indicate that the top three most important initiatives are: ensure staff have a teaching qualification (4.50), use of technology to enhance learning (4.13) and staff mentoring aimed at developing professional excellence (4.00).

In terms of awareness of the thirteen initiatives in Table 2, Panel A, the results show that the students are mostly aware of (1) the provision of guest lectures, (2) use of microphones and (3) the use of technology to enhance learning, respectively. Speaking about the positive impact of guest lectures, a focus group participant asserted: 'The lecturer made the course interesting, it wasn't just 'this is theory, this is what it is', he gave real life examples and experiences and brought in a couple of guest lecturers. It wasn't an overboard of 5 different lectures, there was a variety of different techniques he used to get his points across'.

The results also show that the students are least aware of (1) staff development through voice coaching, (2) student experience budget and (3) student union -TEL initiatives which are ranked 13,12 and 11 , respectively.

\section{[Table 2 ABOUT HERE]}

The one sample t-test for all the thirteen initiatives comparing their mean rating with the neutral point rating of ' 3 ' determines which of the initiatives are statistically important. The results indicate that eight of the initiatives are statistically important at $1 \%$ level. In addition to the three described as important in terms of the mean ranking, the use of microphones, sharing 
good practice through peer review, AACSB accreditation, staff sharing experiences through an education enhancement forum and in-house teacher training are found to be significantly important. Although the mean rating of initiative number 11 'Student Union-TEL initiatives' is significantly different from the neutral point of 3 on the Likert scale, this means that the initiative is statistically unimportant. Using the same t-tests, the results show that statistically, students are only significantly aware of the provision of guest lectures, use of microphones and the use of technology to enhance learning initiatives.

Since there is evidence to suggest students' satisfaction improves if the students are aware of the initiatives (Nasser, Khoury, and Abouchedid 2008), the researchers ran a correlation co-efficient test between the mean rating of the importance and awareness for those initiatives with a mean rating of above 3 (the neutral point) found to be statistically significant. The results, which are presented in Table 2, Panel B, indicate that out of the eight initiatives, there are only three instances where there are significant positive correlations between importance and awareness (i.e. sharing good practice through peer review, sharing good practice through an education enhancement forum and in-house teacher training). This is evidence that students are mostly unaware of important initiatives undertaken within this Department.

\subsubsection{Assessment \& Feedback}

Feedback is the area of greatest discontent among students surveyed regarding their course. The following transcript from one focus group supports this assertion:

Researcher: The questionnaire result showed that timely and quality feedback is the most important initiative, is it true, is that what you rated?

Student A: $\quad$ Yeah, especially when you get late feedback or late marks. 
Student D: $\quad$ I think one of the things that annoyed people I know is when lecturers have gone past the deadline for coursework and you get it back and it just says '60-65' or 'good' and you are like 'ok, what did I do wrong'. They give you no indication on how you failed or how you didn't get 70+ etc. or for example if you got 45, it just says you missed out on this point.

Researcher: Are you saying you want detailed feedback?

Student D: $\quad$ Yeah, so normally it's a sentence or a few words they do instead of like a paragraph, it's generally not very helpful.

Student C: I completely agree the quality of feedback is the most important thing in this section, and it's the one thing that needs to be improved.

According to the results in Table 3, Panel A, it is therefore not surprising that the initiatives aimed at improving student satisfaction to NSS questions on assessment and feedback are regarded as very important. Table 3, Panel A, shows that all twelve initiatives that the Department implemented are significantly important at $1 \%$ level from the neutral point of ' 3 ' on the Likert scale. The most important initiative based on the mean rating is the timely and good quality feedback (4.68), followed by the three-week turnaround for marking assignments (4.62) and the electronic marking and feedback (4.36) is ranked third.

Despite the fact that all initiatives are perceived to be important by the students, an examination of student awareness paints a different picture. For example, the mean rating of the awareness of the 12 initiatives indicate that only five out of the 12 initiatives have a mean rating of above 3. Further, in terms of significant awareness, the results suggest that students are significantly aware of only four such initiatives: electronic marking and feedback, three- 
week turn around for marking coursework, marking criteria and standardised feedback forms and timely and good quality feedback.

\section{[TABLE 3 ABOUT HERE]}

To examine the association between the importance and awareness of the initiatives on assessment and feedback, the researchers ran correlation analysis between importance and awareness of the twelve significantly important initiatives (initiatives 14 to 25). The results, which are presented in Table 3, Panel B, show that in ten out of the twelve initiatives, there are significant correlations between the importance and awareness of the initiatives. However, the surprising finding is that there is no significant relationship between importance and awareness of initiatives number 15 and 18 which are on 'three week turnaround for marking coursework' and 'internal audit of feedback to ensure good quality', respectively. Both these initiatives are deemed to be very important, as they are ranked second and fifth in terms of importance. Overall, the findings relating to assessment and feedback initiatives suggest that the Department is doing a good job of making sure the students are aware of the important initiatives aimed at improving assessment and feedback.

\subsubsection{Academic Support}

The students also regard 14 initiatives pertaining to academic support introduced by the Department as important. The results of descriptive statistics in Table 4, Panel A, show that the most important initiative is the maximum two-day response to student emails, followed by staff guidance on final year options and thirdly, making sure that student complaints are treated seriously and dealt with appropriately. In terms of statistical significance, the one sample t-test results show that thirteen out of the fourteen initiatives are significantly important. The only initiative not statistically significant is initiative number 31 on the 'promotion of student 
engagement through the GROW programme'. In terms of awareness, the results show that in general, the students are not aware of the initiatives aimed at ensuring more positive responses from students on the NSS questionnaire on questions relating to academic support.

For example, only four out of the fourteen initiatives, receive a mean rating of over the neutral rating of 3 . When the subject of awareness under this category was discussed at the focus group, a participant asserted: 'I think most people are not aware of this [2-day response to emails]. A number of lecturers do not stick to the time constraint. I had to wait for a month before the exams and the lecturer replied on the day of the exams. Most people are not aware as most don't stick to it'.

This confirms the results of a questionnaire survey in Table 4 which show that the students are statistically aware of just three (initiatives 26, 27 and 34) of the fourteen initiatives.

\section{[TABLE 4 ABOUT HERE]}

The correlation test results to determine whether there is a relationship between importance and awareness of the statistically important initiatives are presented in Table 4, Panel B. The results show that there is a significant relationship between importance and awareness in only six out of the fourteen initiatives. This suggests that despite the students' perceptions of the various initiatives as significantly important, they are not aware of these initiatives. This again suggests the need for the Department to improve its communications regarding initiatives taken ensuring students are made aware of all the important undertakings.

\subsubsection{Organisation and Management}

Table 5, Panel A, shows the results of the importance and awareness of the ten initiatives (40 to 49) that the Department introduced to reverse the decline in students' responses to the questions on organisation and management on the NSS questionnaire. The 
results show that the students regard 'no charge to see exam scripts' as the most important initiative, followed by staff not being allowed leave or conference attendance while teaching or marking is required and the standardised assignment briefs is rated as the third most important. The ranking of 'no charge to see exam scripts' as the most important initiative is no surprise given that previously the students had to pay a $£ 10$ fee to see their marked examination script.

\section{[TABLE 5 ABOUT HERE]}

In terms of the significance of the importance of the items, the results in Table 5, Panel A, show that eight out of the ten items are significantly important. The only two items not significantly important are 'the availability of framework leaders and programme coordinators photographs' and 'loop-closing' through 'you said, this happened'. Regarding the awareness of the ten initiatives, the results show that the students are not significantly aware of any of the initiatives. It is clear from the mean rating of the awareness of the initiatives that only three such initiatives have a mean rating above the neutral rating of 3 . These initiatives are standardised assignment briefs, unit guide explicit on course integration, and clear communication of any changes in management structure.

The results of the correlation between the importance and awareness of the eight significantly important initiatives are presented in Table 5, Panel B. The results show that there are significant correlations on only three out of the eight initiatives. These are 'availability of learning technologists' and 'clear communication of any changes in management structure'.

The lack of significant correlations between the importance and awareness of the other initiatives suggest that the Department has not taken the opportunity to explain to students the 
initiatives aimed at improving the NSS questionnaire responses. This was clearly evident during the focus group discussions when one student remarked: 'I did not know that staff were not supposed to take annual leave or attend a conference when teaching and marking was required. How am I supposed to know?'

While staff not being allowed to take annual leave or attend a conference is a managerial issue, the results suggest that student satisfaction could be enhanced if they are made aware of the initiative.

\subsubsection{Learning Resources}

The results of the ratings of importance and awareness of the two initiatives associated with the learning and resources questions on the NSS questionnaire are presented in Table 6, Panel A. The results show that accessibility of core textbooks by promoting the use of e-books initiative is regarded as more important and the availability of IT resources and other facilities is second. The t-tests show that the two initiatives are both significantly important at $1 \%$ level. In terms of awareness, the results indicate that the students are slightly more aware of the availability of IT resources and other facilities than the accessibility of core texts by promoting the use of ebooks in terms of the mean ranking. The results of the t-tests also show that students are significantly aware of both initiatives.

\section{[TABLE 6 ABOUT HERE]}

The results of correlation analysis test are shown in Table 6, Panel B. These results show that although there is a significant correlation between the importance and awareness of 
the availability of IT resources and other facilities, there is no significant relationship between the importance and awareness of the accessibility of core texts by the promotion of ebooks.

\subsubsection{Personal Development}

The results in respect of personal development initiatives are presented in Table 7, Panel A. These results show that out of the six initiatives, the enhancement of numeracy skills is regarded as most important, followed by the encouragement of engagement between students and employers through provisions of post placement, industry mentors. In terms of the significance of the importance of the initiatives, the results show that only three out of the six initiatives are significantly important. Regarding the awareness of the initiatives, the results show that only three such initiatives have mean ratings of above the neutral rating of 3 . The ttest results, however, reveal that students are not significantly aware of any of the six initiatives.

\section{[TABLE 7 ABOUT HERE]}

The correlation between the significantly important personal development initiatives and the student awareness is presented in Table 7, Panel B. The results show that there is no significant relationship between the importance and awareness of the initiatives. This again suggests that the Department needs to do more in terms of making sure that students are aware of the important initiatives in order to improve the student satisfaction in terms of responding to the NSS questionnaire.

\subsubsection{Other Initiatives Suggested by the Students}


Section $\mathrm{C}$ of the questionnaire (see Appendix 1) administered to the students asked the students to list any other initiatives they regard as important. Under the teaching section, four points were raised by the students. Firstly, they stated that the lecturer must be qualified. The students felt that it is essential that lecturers on final year units have previous experience and appropriate qualifications. Secondly, the students also made the point that the lecturers must be understandable, noting that in some cases lecturers' accents can impede the delivery of already challenging material. Thirdly, the students also wanted the lectures recorded so that they could listen when revising for exams as well as throughout the course. Fourthly, students preferred to have the same lecturer throughout a module rather than experience a change in lecturer mid-semester. The following assertions from participants stressed the need for qualified teachers:

Student B - Maybe the university should appoint those who are less qualified to teach level C [first year] and not level H [final year]. We don't want a PHD candidate who has no clue what she is talking about in a level $H$ unit when this year is really important for $70 \%$ of our overall mark. If she was shifted down a bit or not at all it would be better.

Student $C-\quad I$ think it is important that they are actually prepared for the lecture and they know what's exactly on the slides, they know what they are going to say, they know the subject, so if a question comes up, they can then answer it. Most lecturers are good but some you can tell they haven't prepared and their slides show that. 
Student E - Hire those lecturers who are really approachable and the ones who want to be here at university and they want to help out students, rather than those who are here just to answer a few questions and then go home. It's a 2-way thing, we are going to be in debt and they are getting paid, so they should help us as one day we may be lecturers and helping their kids.

In terms of assessment and feedback, the students stated that they want exam results released early. This point was made by ten students. Most of the students stated that it had been six weeks since they had sat the first semester exams but had yet to receive their results. The students also stated that they want more feedback in terms of positive as well as negative comments and how the candidate could improve in future. Further, they also stated that they want the marked assignment returned in 3 weeks. They are aware that there is a policy in place but feel that this is not being adhered to in some cases. Some students also feel that the feedback should be personalised, for example, delivered face-to-face.

Under the academic support, the students listed two additional points. They would like one-to-one support for coursework and also more contact with the academic advisors. One student commented that academic advisors should identify themselves by email.

Under organisation and management, one student stated that the Department should inform students what is going on, and went on to say that: 'I had not heard about most of these initiatives'. Another point made was that the Department should make the timetable more convenient. For example, two students stated that they had a lecture at 9 am followed by lectures at $3 \mathrm{pm}$ and $6 \mathrm{pm}$. Many students noted that the timetabling is bad as lectures could be spread from 9 am-7pm with only 4 hours of lectures. 
In terms of learning resources, the students want more recommended textbooks in the library. Two students stated that they spent $£ 50.00$ each term on books which was very expensive for them.

Regarding personal development, the students added that they would like to have final year meetings to discuss future plans and also some help aimed at those who may want to undertake a graduate scheme.

\section{Summary and conclusion}

The NSS questionnaire results for individual courses are important for both the department that runs the course and the university. This is because such results determine the ranking of the course delivered by the department and ultimately the university's league table position. As a result, many departments put resources in the form of various initiatives to improve their subject area and university NSS results. However, there is sparse literature on whether such initiatives are viewed as important by the students and also if the students are aware of such initiatives.

Final year accounting and finance students were surveyed on their perception of the importance and awareness of 57 initiatives put in place by one department at a university in the South of England over a five-year period. The results indicate that while the students regard many of the initiatives as important, they are simply not aware of their implementation. Correlation analysis between the initiatives found to be significantly important to students for their satisfaction and their awareness of the undertakings reveal that in most cases the association is not significant. This means that the Department is failing to improve students' satisfaction because the students are simply not aware of the many initiatives implemented.

The results of the study should be interpreted in the light of the following limitations. First, the study used cross-sectional data which meant the dynamic link between year of study 
and student satisfaction could not be identified. The study is also limited because it is based on a case study in one department at a single university. It is also possible that the findings of this study may not apply the rest of the UK. Another limitation of the study is the low response rate of $54.28 \%$. Although this is high compared to other studies, the response rate could have been higher given that it was administered by fellow students. Finally, like any other questionnaire survey, the study is prone to response bias which could not be tested given that the respondents were anonymous.

Despite the limitations, the research makes three main contributions to existing literature. First, it brings to the fore a comprehensive list of initiatives aimed at improving NSS results. Second, although other studies have documented some initiatives that are put in place to improve NSS results, there is currently no documented evidence of how important those initiatives are in terms of improving the NSS questionnaire results. Finally, the paper extends the existing literature by reflecting on the association between initiatives deemed to be important and students' awareness of their undertakings. The findings suggest that in many cases students are not aware of important initiatives that could improve their satisfaction. This paper therefore advances that the Departments needs to make sure that the important initiatives put in place to improve student satisfaction and NSS questionnaire results are well communicated to students for greatest impact. Whilst the findings from this study may inform practices aimed at improving student satisfaction in similar contexts within Higher Education, a further study with a larger sample sizes involving more institutions will enhance the basis for generalisation across the sector. 


\section{References}

Aronson, Jodi. 1995. "A pragmatic view of thematic analysis." The qualitative report 2, no. 1: $1-3$.

Boyatzis, Richard E. 1998. Transforming qualitative information: Thematic analysis and code development. Sage.

Brown, Sally. 2011. "Bringing about positive change in the higher education student experience: a case study." Quality Assurance in Education 19, no. 3: 195-207. Http://dx.doi.org/10.1108/09684881111158027

Fereday, Jennifer, and Eimear Muir-Cochrane. 2006. "Demonstrating rigor using thematic analysis: A hybrid approach of inductive and deductive coding and theme development." International journal of qualitative methods 5, no. 1: 80-92.

Flint, Abbi, Anne Oxley, Paul Helm, and Sally Bradley. 2009. "Preparing for success: one institution's aspirational and student focused response to the National Student Survey." Teaching in Higher Education 14, no. 6: 607-618. Http://dx.doi.org/10.1080/13562510903315035

Ginns, Paul, Michael Prosser, and Simon Barrie. 2007. "Students' perceptions of teaching quality in higher education: The perspective of currently enrolled students." Studies in Higher Education 32, no. 5: 603-615. Http://dx.doi.org/10.1080/03075070701573773

Kane, David, James Williams, and Gillian Cappuccini-Ansfield. 2008. "Student satisfaction surveys: The value in taking an historical perspective." Quality in Higher Education 14, no. 2: 135-155. Http://dx.doi.org/10.1080/13538320802278347

Kitzinger, Jenny. 1995. "Qualitative research. Introducing focus groups." BMJ: British medical journal 311, no. 7000: 299.

Kovacs, Szerenke, Lyndsay Grant, and Fiona Hyland. 2010. "A study of the use of the National Student Survey to enhance the Student Experience in Education." Higher Education Academy.

Lenton, Pamela. 2015. "Determining student satisfaction: An economic analysis of the National Student Survey." Economics of Education Review 47: 118-127. Https://doi.org/10.1016/j.econedurev.2015.05.001

Morgan, David L. 1996. "Focus groups." Annual review of sociology 22, no. 1: 129-152.

Nasser, Ramzi N., Bechara Khoury, and Kamal Abouchedid. 2008. "University students' knowledge of services and programs in relation to satisfaction: a case study of a private university in Lebanon." Quality Assurance in Education 16, no. 1: 80-97. Http://dx.doi.org/10.1108/09684880810848422

Race, Phil. Ed. 2010. Increasing Students' Satisfaction. 11 $11^{\text {th }}$ Issue of Reflections. Queen's University Belfast.

Ryan, Gery W., and H. Russell Bernard. 2003. "Techniques to identify themes."Field methods 15, no. 1: 85-109.

Sterba, SKl, and E. M. Foster. 2008. "Self-selected sample." Encyclopedia of survey research methods: 806-808.

Torres, Julie West.2004. "Speaking up! Adult ESL students' perceptions of native and nonnative English speaking teachers."

Wainer, Howard. 1986. "The SAT as a social indicator: A pretty bad idea." InDrawing inferences from self-selected samples, pp. 7-21. Springer New York.

Wolcott, Harry F. 1994. Transforming qualitative data: Description, analysis, and interpretation. Sage. 


\begin{tabular}{|c|c|c|c|c|}
\hline & & & No & Percentage \\
\hline \multirow[t]{3}{*}{ 1.Gender } & & Female & 34 & 59.60 \\
\hline & & Male & $\underline{23}$ & $\underline{40.40}$ \\
\hline & & & 57 & 100.00 \\
\hline \multirow[t]{5}{*}{ 2.Expected degree classification } & & $1 \mathrm{st}$ & 14 & 24.56 \\
\hline & & 2.1 & 40 & 70.18 \\
\hline & & 2.2 & 3 & 5.26 \\
\hline & & 3 & $\underline{0}$ & $\underline{0.00}$ \\
\hline & & & 57 & 100.00 \\
\hline \multirow[t]{3}{*}{ 3.Awareness of NSS } & & Aware & 54 & 94.74 \\
\hline & & Not Aware & $\underline{3}$ & 5.26 \\
\hline & & & 57 & 100.00 \\
\hline \multirow[t]{3}{*}{ 4. Completed or intent to complete NSS survey } & & Yes & 43 & 75.44 \\
\hline & & No & 14 & $\underline{24.56}$ \\
\hline & & & 57 & 100.00 \\
\hline 5. Level of satisfaction over course duration & $\mathrm{N}$ & Mean* & Min & $\operatorname{Max}$ \\
\hline 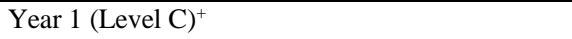 & 53 & 3.74 & 1 & 5 \\
\hline Year 2 (Level I) & 57 & 3.63 & 1 & 5 \\
\hline Year $3\left(\right.$ Level P) ${ }^{+}$ & 47 & 4.27 & 1 & 5 \\
\hline Year 4 (Level H) & 57 & 3.72 & 1 & 5 \\
\hline
\end{tabular}

+ 4 students were direct entries into Year 2 (Level I); ten students had not undertaken a placement year. 


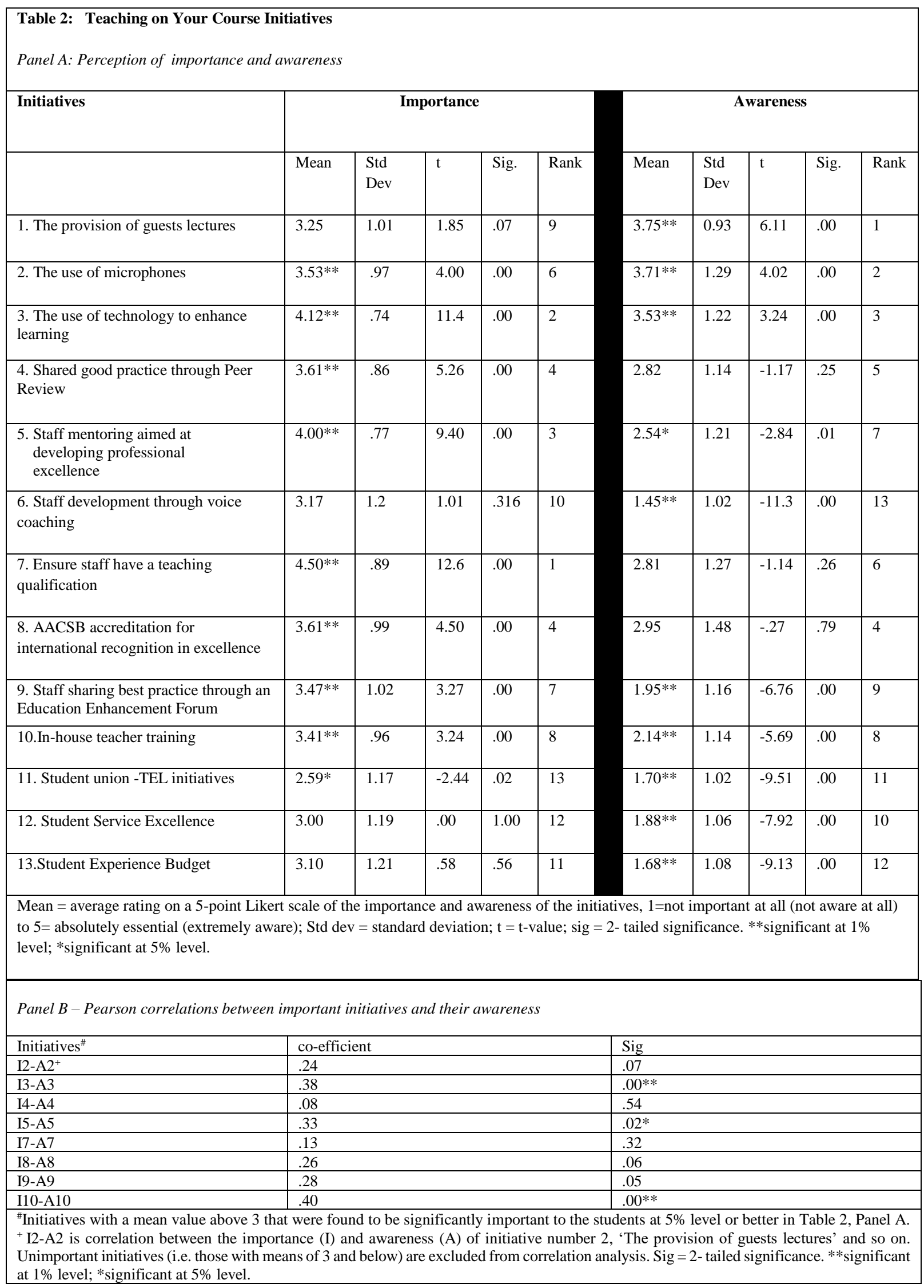




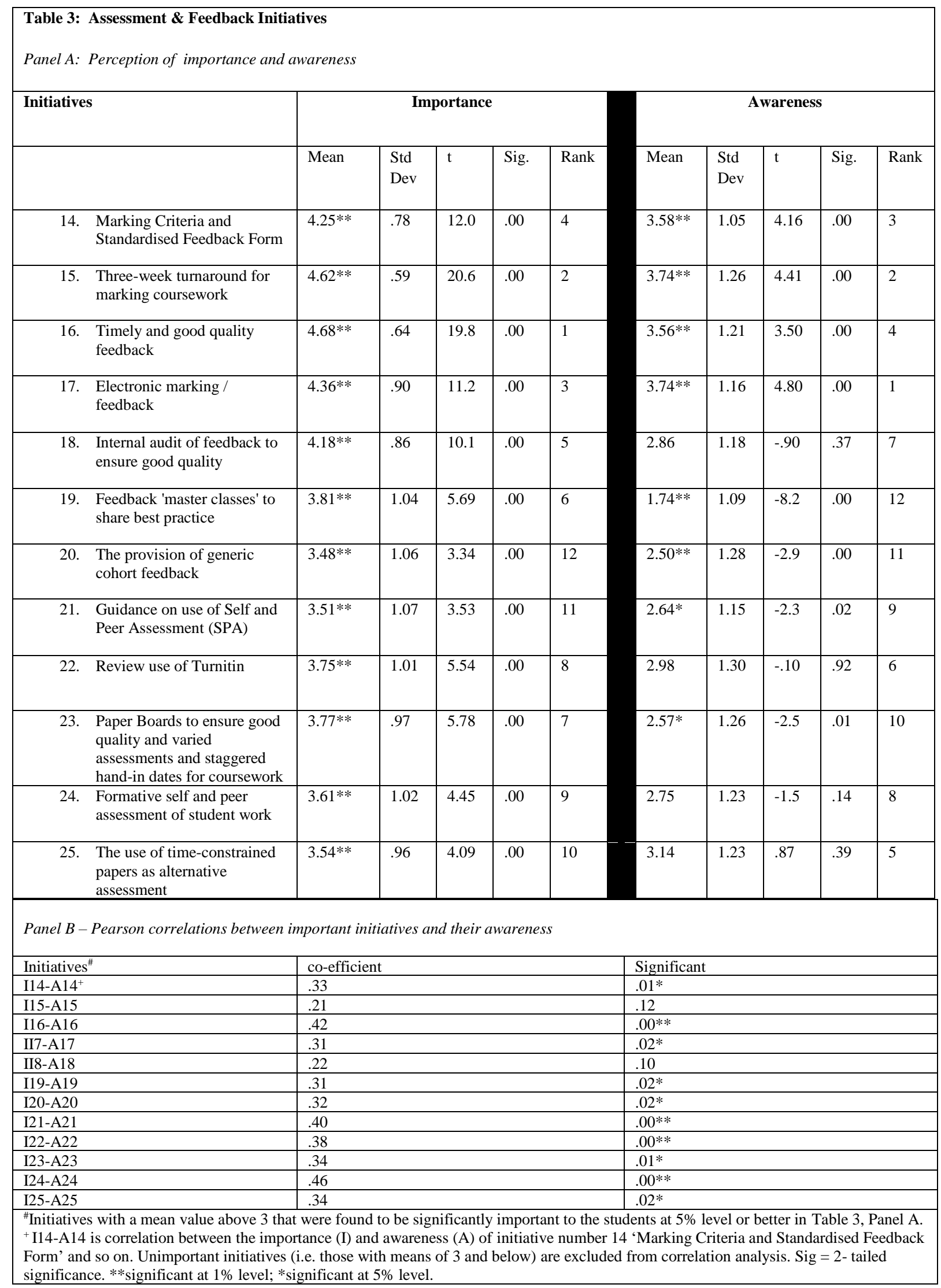




\begin{tabular}{|c|c|c|c|c|c|c|c|c|c|c|}
\hline \multirow[t]{2}{*}{ Initiatives } & \multicolumn{5}{|c|}{ Importance } & \multicolumn{5}{|c|}{ Awareness } \\
\hline & Mean & $\begin{array}{l}\text { Std } \\
\text { Dev }\end{array}$ & $\mathrm{t}$ & Sig. & Rank & Mean & $\begin{array}{l}\text { Std } \\
\text { Dev }\end{array}$ & $\mathrm{T}$ & Sig. & Rank \\
\hline 26. Publication of surgery times & $4.28 * *$ & .80 & 11.7 & .00 & 3 & $4.09 * *$ & .90 & 9.06 & .00 & 1 \\
\hline $\begin{array}{l}\text { 27. Maximum 2-day response to } \\
\text { student email }\end{array}$ & $4.54 * *$ & 57 & 19.7 & .00 & 1 & $3.39 *$ & 1.26 & 2.31 & .03 & 2 \\
\hline $\begin{array}{l}28 \text {. Target Level } \mathrm{H} \text { lower quartile and } \\
\text { boundary students }\left(+2 \% \text { on } 1^{\text {st }} \text { or } 2: 1\right. \\
\text { grade bands). Advise on engagement } \\
\text { and University regulations }\end{array}$ & $4.19 * *$ & .86 & 9.95 & .00 & 5 & 2.80 & 1.46 & -1.0 & -.20 & 7 \\
\hline $\begin{array}{l}\text { 29. Identify students most at risk } \\
\text { (Level H) and offer support }\end{array}$ & $4.08 * *$ & .91 & 8.80 & .00 & 6 & $2.28 * *$ & 1.14 & -4.7 & .00 & 10 \\
\hline $\begin{array}{l}\text { 30. Appoint staff to support } \\
\text { international students }\end{array}$ & $3.61 * *$ & 1.07 & 4.19 & .00 & 11 & $2.14 * *$ & 1.17 & -5.5 & .00 & 14 \\
\hline $\begin{array}{l}\text { 31. Promotion of student engagement } \\
\text { through GROW }\end{array}$ & 3.16 & 1.11 & 1.08 & .28 & 14 & $2.21 * *$ & 1.35 & -4.4 & .00 & 12 \\
\hline $\begin{array}{l}\text { 32. Ensure student complaints are } \\
\text { treated seriously and dealt with } \\
\text { appropriately }\end{array}$ & $4.27 * *$ & .99 & 9.54 & .00 & 3 & 2.93 & 1.18 & -.45 & .65 & 6 \\
\hline 33. Staff guidance on Level H options & $4.33 * *$ & .88 & 11.1 & .00 & 2 & 3.07 & 1.32 & .40 & .69 & 4 \\
\hline $\begin{array}{l}\text { 34. Support for students with } \\
\text { Additional Learning Needs (ALN) }\end{array}$ & $4.05 * *$ & 1.08 & 7.2 & .00 & 7 & $3.38^{*}$ & 1.24 & 2.26 & .03 & 3 \\
\hline $\begin{array}{l}\text { 35. Student Expectations - Student } \\
\text { Charter }\end{array}$ & $3.41^{*}$ & 1.12 & 2.56 & .01 & 13 & $2.21 * *$ & 1.29 & -4.5 & .00 & 12 \\
\hline $\begin{array}{l}\text { 36. Provision of academic advice by } \\
\text { Programme Coordinators }\end{array}$ & $3.81 * *$ & .92 & 6.41 & .00 & 9 & $2.65^{*}$ & 1.12 & -2.3 & .03 & 9 \\
\hline $\begin{array}{l}\text { 37. Provision of individual } \\
\text { Academic Advisors }\end{array}$ & $3.57 * *$ & 1.05 & 3.94 & .00 & 12 & 2.72 & 1.24 & -1.7 & .09 & 8 \\
\hline $\begin{array}{l}\text { 38. Mathematic and Statistics Help } \\
\text { Centre }\end{array}$ & $3.83 * *$ & 1.21 & 5.06 & .00 & 8 & $2.25 * *$ & 1.32 & -4.2 & .00 & 11 \\
\hline 39. Study skills support & $3.73^{* *}$ & 1.11 & 4.84 & .00 & 10 & 2.98 & 1.26 & -.11 & .92 & 5 \\
\hline \multicolumn{11}{|c|}{ Panel B - Pearson correlations between important initiatives and their awareness } \\
\hline Initiatives ${ }^{\#}$ & \multicolumn{5}{|c|}{ Co-efficient } & \multicolumn{5}{|c|}{ Significant } \\
\hline I26-A26+ & \multicolumn{5}{|c|}{.40} & \multicolumn{5}{|c|}{$.00^{*}$} \\
\hline I27-A27 & \multicolumn{5}{|l|}{.03} & \multicolumn{5}{|l|}{.82} \\
\hline I28-A28 & \multicolumn{5}{|l|}{.32} & \multicolumn{5}{|l|}{$.02 *$} \\
\hline I29-A29 & \multicolumn{5}{|l|}{.02} & \multicolumn{5}{|l|}{.91} \\
\hline I30-A30 & \multicolumn{5}{|l|}{.24} & \multicolumn{5}{|l|}{.07} \\
\hline I32-A32 & \multicolumn{5}{|l|}{.27} & \multicolumn{5}{|l|}{$.04 *$} \\
\hline I33-A33 & \multicolumn{5}{|l|}{.39} & \multicolumn{5}{|l|}{$.00^{* *}$} \\
\hline I34-A34 & \multicolumn{5}{|l|}{.12} & \multicolumn{5}{|l|}{.37} \\
\hline I35-A35 & \multicolumn{5}{|l|}{.41} & \multicolumn{5}{|l|}{$.00^{* *}$} \\
\hline I36-A36 & \multicolumn{5}{|l|}{.26} & \multicolumn{5}{|l|}{.06} \\
\hline I37-A37 & \multicolumn{5}{|l|}{.22} & \multicolumn{5}{|l|}{.11} \\
\hline I38-A38 & .17 & & & & & .22 & & & & \\
\hline I39-A39 & .48 & & & & & $.00^{* *}$ & & & & \\
\hline
\end{tabular}




\begin{tabular}{|c|c|c|c|c|c|c|c|c|c|c|}
\hline \multirow[t]{2}{*}{ Initiatives } & \multicolumn{5}{|c|}{ Importance } & \multicolumn{5}{|c|}{ Awareness } \\
\hline & Mean & $\begin{array}{l}\text { Std } \\
\text { Dev }\end{array}$ & $\mathrm{t}$ & Sig. & Rank & Mean & $\begin{array}{l}\text { Std } \\
\text { Dev }\end{array}$ & $\mathrm{t}$ & Sig. & Rank \\
\hline $\begin{array}{l}\text { 40. Time-table changes with } \\
\text { Head of Department } \\
\text { approval }\end{array}$ & $3.71 * *$ & .98 & 5.26 & .00 & 6 & $2.62 *$ & 1.33 & -2.11 & .04 & 5 \\
\hline $\begin{array}{l}\text { 41. No staff leave or conference } \\
\text { attendance while Teaching } \\
\text { and/or marking is required }\end{array}$ & $4.18 * *$ & 1.01 & 8.61 & .00 & 2 & $2.38^{* * *}$ & 1.28 & -3.57 & .00 & 8 \\
\hline $\begin{array}{l}\text { 42. Standarised Assignment } \\
\text { briefs }\end{array}$ & $4.12 * *$ & .88 & 9.62 & .00 & 3 & 3.14 & 1.20 & .88 & .38 & 2 \\
\hline $\begin{array}{l}\text { 43. Unit guide explicit on course } \\
\text { integration }\end{array}$ & $4.09 * *$ & .90 & 8.81 & .00 & 4 & 3.24 & 1.21 & 1.44 & .15 & 1 \\
\hline $\begin{array}{l}\text { 44. } \begin{array}{l}\text { No charge to see exam } \\
\text { scripts }\end{array}\end{array}$ & $4.46^{* *}$ & .77 & 13.9 & .00 & 1 & 2.63 & 1.63 & -1.70 & .09 & 4 \\
\hline $\begin{array}{l}\text { 45. Ensure effective 'crisis } \\
\text { management' }\end{array}$ & $3.75 * *$ & 1.18 & 4.68 & .00 & 5 & $2.58^{*}$ & 1.36 & -2.28 & .03 & 6 \\
\hline $\begin{array}{l}\text { 46. Availability of Framework } \\
\text { Leaders and Programme } \\
\text { Coordinators photographs }\end{array}$ & 2.90 & 1.36 & -.50 & .62 & 10 & $2.58^{*}$ & 1.36 & -2.28 & .03 & 6 \\
\hline $\begin{array}{l}\text { 47. 'Loop-closing' through "You } \\
\text { said, This Happened" }\end{array}$ & 3.32 & 1.22 & 1.86 & .07 & 9 & $2.05 * *$ & 1.14 & -6.12 & .00 & 10 \\
\hline $\begin{array}{ll}\text { 48. Availability of Learning } \\
\text { Technologists }\end{array}$ & $3.38^{*}$ & 1.26 & 2.13 & .04 & 8 & $2.23 * *$ & 1.33 & -4.30 & .00 & 9 \\
\hline $\begin{array}{ll}\text { 49. } & \begin{array}{l}\text { Clear communication of any } \\
\text { changes in Management } \\
\text { Structure }\end{array} \\
\end{array}$ & $3.40^{*}$ & 1.23 & 2.42 & .02 & 7 & 3.07 & 1.21 & .44 & .66 & 3 \\
\hline \multicolumn{11}{|c|}{ Panel B-Pearson correlations between important initiatives and their awareness } \\
\hline Initiatives $^{\#}$ & \multicolumn{5}{|c|}{ Co-efficient } & \multicolumn{5}{|l|}{ Significant } \\
\hline I40-A $40^{+}$ & \multicolumn{5}{|c|}{.24} & \multicolumn{5}{|c|}{.08} \\
\hline I41-A41 & \multicolumn{5}{|l|}{-.03} & \multicolumn{5}{|l|}{.84} \\
\hline $\mathrm{I} 42-\mathrm{A} 42$ & \multicolumn{5}{|l|}{.23} & \multicolumn{5}{|l|}{.09} \\
\hline I43-A43 & \multicolumn{5}{|l|}{.19} & \multicolumn{5}{|l|}{.17} \\
\hline I44-A44 & \multicolumn{5}{|l|}{.13} & \multicolumn{5}{|l|}{.34} \\
\hline I45-A45 & \multicolumn{5}{|l|}{.50} & \multicolumn{5}{|l|}{$.00^{* *}$} \\
\hline I48-A48 & \multicolumn{5}{|l|}{.55} & \multicolumn{5}{|l|}{$.00 * *$} \\
\hline I49-A49 & \multicolumn{5}{|l|}{.52} & \multicolumn{5}{|l|}{$.00 * *$} \\
\hline
\end{tabular}




\begin{tabular}{|c|c|c|c|c|c|c|c|c|c|c|}
\hline \multirow[t]{2}{*}{ Initiatives } & \multicolumn{5}{|c|}{ Importance } & \multicolumn{5}{|c|}{ Awareness } \\
\hline & Mean & $\begin{array}{l}\text { Std } \\
\text { Dev }\end{array}$ & $\mathrm{t}$ & Sig. & Rank & Mean & $\begin{array}{l}\text { Std } \\
\text { Dev }\end{array}$ & $\mathrm{t}$ & Sig. & Rank \\
\hline $\begin{array}{l}\text { 50. Accessibility of Core texts } \\
\text { by promoting the use of } \\
\text { eBooks }\end{array}$ & $4.46^{* * *}$ & .83 & 13.2 & .00 & 1 & $3.93 * *$ & 1.03 & 6.80 & .00 & 2 \\
\hline $\begin{array}{l}\text { 51. Availability of IT resources } \\
\text { and other facilities }\end{array}$ & $4.43 * *$ & .87 & 12.3 & .00 & 2 & $3.94 * *$ & .91 & 7.82 & .00 & 1 \\
\hline \multicolumn{11}{|c|}{ Panel B: Pearson correlations between important initiatives and their awareness } \\
\hline Initiatives $^{\#}$ & \multicolumn{5}{|c|}{ Co-efficient } & \multicolumn{5}{|c|}{ Significant } \\
\hline I50I-A50 $0^{+}$ & \multicolumn{5}{|c|}{.16} & \multicolumn{5}{|c|}{.22} \\
\hline I51-A51 & \multicolumn{5}{|l|}{.30} & \multicolumn{5}{|l|}{$.02 *$} \\
\hline \multicolumn{11}{|c|}{$\begin{array}{l}\text { "Initiatives with a mean value above } 3 \text { that were found to be significantly important to the students at } 5 \% \text { level or better in Table } 6 \text {, Panel A } \\
\text { + I50-A50 is correlation between the importance (I) and awareness (A) of initiative number } 50 \text { 'Accessibility of Core texts by promoting the } \\
\text { use of eBooks' and so on. Unimportant initiatives (i.e. those with means of } 3 \text { and below) are excluded from correlation analysis. Sig = 2- } \\
\text { tailed significance. **significant at } 1 \% \text { level; *significant at 5\% level. }\end{array}$} \\
\hline
\end{tabular}




\begin{tabular}{|c|c|c|c|c|c|c|c|c|c|c|}
\hline \multicolumn{11}{|c|}{$\begin{array}{l}\text { Table 7: Personal Development Initiatives } \\
\text { Panel A: Perception of importance and awareness }\end{array}$} \\
\hline \multirow[t]{2}{*}{ Initiatives } & \multicolumn{5}{|c|}{ Importance } & \multicolumn{5}{|c|}{ Awareness } \\
\hline & Mean & $\begin{array}{l}\text { Std } \\
\text { Dev }\end{array}$ & $\mathrm{t}$ & Sig. & Rank & Mean & $\begin{array}{l}\text { Std } \\
\text { Dev }\end{array}$ & $\mathrm{t}$ & Sig. & Rank \\
\hline $\begin{array}{l}\text { 52. } \\
\text { Encourage engagement } \\
\text { between students and } \\
\text { employers through the } \\
\text { provision of post- } \\
\text { placement/industry mentors }\end{array}$ & $4.16^{* *}$ & .98 & 8.83 & .00 & 2 & 3.07 & 1.31 & .41 & .68 & 2 \\
\hline 53. Extend and embed 'Mahara' & 2.87 & 1.13 & -.85 & .40 & 6 & 3.18 & 1.21 & 1.11 & .27 & 1 \\
\hline $\begin{array}{l}\text { 54. Continue to promote } \\
\text { 'Student Development } \\
\text { Award' }\end{array}$ & 3.18 & 1.19 & 1.14 & .26 & 4 & 3.02 & 1.10 & .12 & .90 & 3 \\
\hline $\begin{array}{ll}\text { 55. Promotion of Academic } \\
\text { Societies }\end{array}$ & 3.17 & 1.06 & 1.16 & .25 & 5 & 2.64 & 1.08 & -2.5 & .02 & 5 \\
\hline $\begin{array}{l}\text { 56. Provision of an Outduction } \\
\text { and Level H support }\end{array}$ & $3.54 * *$ & .98 & 4.14 & .00 & 3 & $2.04 * *$ & 1.17 & -6.14 & .00 & 6 \\
\hline $\begin{array}{l}\text { 57. Enhancement of numeracy } \\
\text { skills and excel training }\end{array}$ & $4.34 * *$ & .82 & 12.1 & .00 & 1 & 2.91 & 1.25 & -.53 & .60 & 4 \\
\hline \multicolumn{11}{|c|}{ Panel B: Pearson correlations between important initiatives and their awareness } \\
\hline Initiatives $^{\#}$ & \multicolumn{5}{|c|}{ Co-efficient } & \multicolumn{5}{|c|}{ Significant } \\
\hline${\mathrm{I} 52-\mathrm{A} 52^{+}}^{+}$ & \multicolumn{5}{|c|}{.25} & \multicolumn{5}{|c|}{.06} \\
\hline I56-A56 & \multicolumn{5}{|l|}{.07} & \multicolumn{5}{|l|}{.63} \\
\hline I57-A57 & \multicolumn{5}{|l|}{.20} & \multicolumn{5}{|l|}{.15} \\
\hline \multicolumn{11}{|c|}{$\begin{array}{l}\text { "Initiatives with a mean value above } 3 \text { that were found to be significantly important to the students at } 5 \% \text { level or better in Table } 7 \text {, Panel A. } \\
{ }^{+} \text {I52-A52 is correlation between the importance (I) and awareness (A) of initiative number } 52 \text { 'Encourage engagement between students } \\
\text { and employers through the provision of post-placement/industry mentors' and so on. Unimportant initiatives (i.e. those with means of } 3 \text { and } \\
\text { below) are excluded from correlation analysis. Sig }=2 \text { - tailed significance. **significant at } 1 \% \text { level; *significant at } 5 \% \text { level. }\end{array}$} \\
\hline
\end{tabular}




\section{Appendix 1- Questionnaire}

If you would like to be entered in the prize draw for participating in this research, please provide us with your student number:

Winners will be notified by 11/03/16.

\section{SECTION A}

\section{BACKGROUND INFORMATION}

In this section, please respond by ticking one box for each question and where appropriate, fill in the blank spaces.

1. What is your gender

1 Female $\square$ 0 Male

2. What degree classification are you expecting based on your results to date?
1 First class
2 Upper second class (2.1)
3 Lower second (2.2) $\square \mathbf{4}$ Third class

3. Are you aware of the National Student Survey?

1 Yes $\square \quad \mathbf{0}$ No

4. Have or are you going to respond to the request to complete the NSS? 1 Yes $\square \mathbf{0}$ No If you have answered no, what is the main reason?

(i) Don't have time to complete the questionnaire

(ii) My responses will not make a difference

\section{1}

(iii) No incentive for me to complete the questionnaire

(iv) The questionnaire is too long

(v) Not very happy with the course but did not want to give negative responses

(vi) Other (please specify)

5. Please indicate your level of satisfaction with your course at the end of each of the following years (levels):

\begin{tabular}{|c|c|c|c|c|c|c|}
\hline & 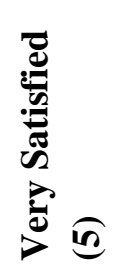 & 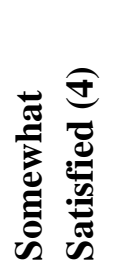 & 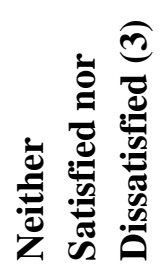 & 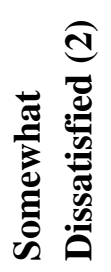 & 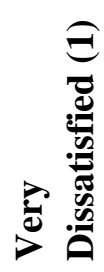 & $\begin{array}{l}\frac{0}{0} \\
\frac{0}{0} \\
\frac{0}{2} \\
\frac{0}{2} \\
\frac{0}{2} \\
z\end{array}$ \\
\hline \multicolumn{7}{|l|}{ Year 1 (Level C) } \\
\hline \multicolumn{7}{|l|}{ Year 2 (Level I) } \\
\hline \multicolumn{7}{|l|}{ Year 3 (Level P) } \\
\hline Year 4 (Level H) & & & & & & \\
\hline
\end{tabular}




\section{AWARENESS AND IMPORTANCE OF INITIATIVES}

\section{SECTION B}

In this section, please indicate the extent of your awareness and the importance that you attach to each of the following initiatives aimed at improving NSS results. Please tick one box under 'Awareness of Initiatives' and one box under 'Importance of Initiatives' for each of the initiatives.

\begin{tabular}{|c|c|c|c|c|c|c|c|c|c|c|}
\hline & \multicolumn{5}{|c|}{$\begin{array}{l}\text { Importance of } \\
\text { Initiatives }\end{array}$} & \multicolumn{5}{|c|}{$\begin{array}{l}\text { Awareness of } \\
\text { Initiatives }\end{array}$} \\
\hline & 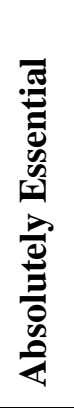 & 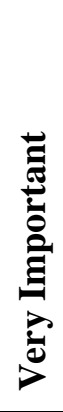 & 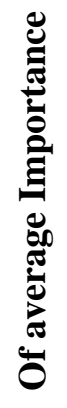 & 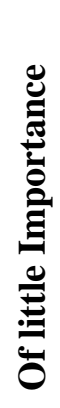 & 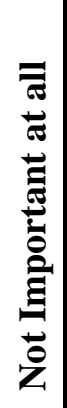 & 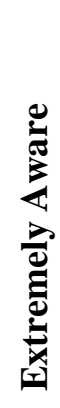 & 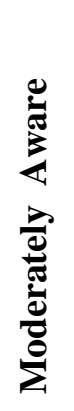 & $\frac{0}{2}$ & 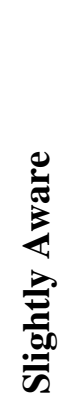 & 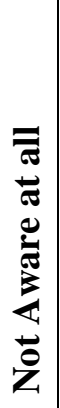 \\
\hline A. TEACHING ON YOUR COURSE & 5 & 4 & 3 & 2 & 1 & 5 & 4 & 3 & 2 & 1 \\
\hline 1. The provision of guests lectures & & & & & & & & & & \\
\hline 2. The use of microphones & & & & & & & & & & \\
\hline $\begin{array}{l}\text { 3. The use of technology to } \\
\text { enhance learning }\end{array}$ & & & & & & & & & & \\
\hline $\begin{array}{l}\text { 4. Shared good practice through } \\
\text { Peer Review }\end{array}$ & & & & & & & & & & \\
\hline $\begin{array}{l}\text { 5. Staff mentoring aimed at } \\
\text { developing professional } \\
\text { excellence }\end{array}$ & & & & & & & & & & \\
\hline $\begin{array}{l}\text { 6. Staff development through voice } \\
\text { coaching }\end{array}$ & & & & & & & & & & \\
\hline $\begin{array}{l}\text { 7. Ensure staff have a teaching } \\
\text { qualification }\end{array}$ & & & & & & & & & & \\
\hline $\begin{array}{l}\text { 8. AACSB accreditation for } \\
\text { international recognition in } \\
\text { excellence }\end{array}$ & & & & & & & & & & \\
\hline $\begin{array}{l}\text { 9. Staff sharing best practice } \\
\text { through an Education } \\
\text { Enhancement Forum }\end{array}$ & & & & & & & & & & \\
\hline 10. In-house teacher training & & & & & & & & & & \\
\hline 11. Student Union-TEL initiatives & & & & & & & & & & \\
\hline
\end{tabular}




\begin{tabular}{|c|c|c|c|c|c|c|c|c|c|c|}
\hline 12. Student Service Excellence & & & & & & & & & & \\
\hline 13. Student Experience Budget & & & & & & & & & & \\
\hline B. ASSESSMENT \& FEEDBACK & 5 & 4 & 3 & 2 & 1 & 5 & 4 & 3 & 2 & 1 \\
\hline $\begin{array}{l}\text { 14. Marking Criteria and } \\
\text { Standardised Feedback Form }\end{array}$ & & & & & & & & & & \\
\hline $\begin{array}{l}\text { 15. Three-week turnaround for } \\
\text { marking coursework }\end{array}$ & & & & & & & & & & \\
\hline $\begin{array}{l}\text { 16. Timely and good quality } \\
\text { feedback }\end{array}$ & & & & & & & & & & \\
\hline 17. Electronic marking / feedback & & & & & & & & & & \\
\hline $\begin{array}{l}\text { 18. Internal audit of feedback to } \\
\text { ensure good quality }\end{array}$ & & & & & & & & & & \\
\hline $\begin{array}{l}\text { 19. Feedback 'master classes' to } \\
\text { share best practice }\end{array}$ & & & & & & & & & & \\
\hline $\begin{array}{l}\text { 20. The provision of generic cohort } \\
\text { feedback }\end{array}$ & & & & & & & & & & \\
\hline $\begin{array}{l}\text { 21. Guidance on use of Self and Peer } \\
\text { Assessment (SPA) }\end{array}$ & & & & & & & & & & \\
\hline 22. Review use of Turnitin & & & & & & & & & & \\
\hline $\begin{array}{l}\text { 23. Paper Boards to ensure good } \\
\text { quality and varied assessments } \\
\text { and staggered hand-in dates for } \\
\text { coursework }\end{array}$ & & & & & & & & & & \\
\hline $\begin{array}{l}\text { 24. Formative self and peer } \\
\text { assessment of student work }\end{array}$ & & & & & & & & & & \\
\hline $\begin{array}{l}\text { 25. The use of time-constrained } \\
\text { papers as alternative assessment }\end{array}$ & & & & & & & & & & \\
\hline C. ACADEMIC SUPPORT & 5 & 4 & 3 & 2 & 1 & 5 & 4 & 3 & 2 & 1 \\
\hline 26. Publication of surgery times & & & & & & & & & & \\
\hline $\begin{array}{l}\text { 27. Maximum 2-day response to } \\
\text { student email }\end{array}$ & & & & & & & & & & \\
\hline $\begin{array}{l}\text { 28. Target Level } \mathrm{H} \text { lower quartile } \\
\text { and boundary students }(+2 \% \text { on } \\
1^{\text {st }} \text { or } 2: 1 \text { grade bands). Advise } \\
\text { on engagement and University } \\
\text { regulations }\end{array}$ & & & & & & & & & & \\
\hline $\begin{array}{l}\text { 29. Identify students most at risk } \\
\text { (Level H) and } \\
\text { offer support }\end{array}$ & & & & & & & & & & \\
\hline $\begin{array}{l}\text { 30. Appoint staff to support } \\
\text { international students }\end{array}$ & & & & & & & & & & \\
\hline
\end{tabular}




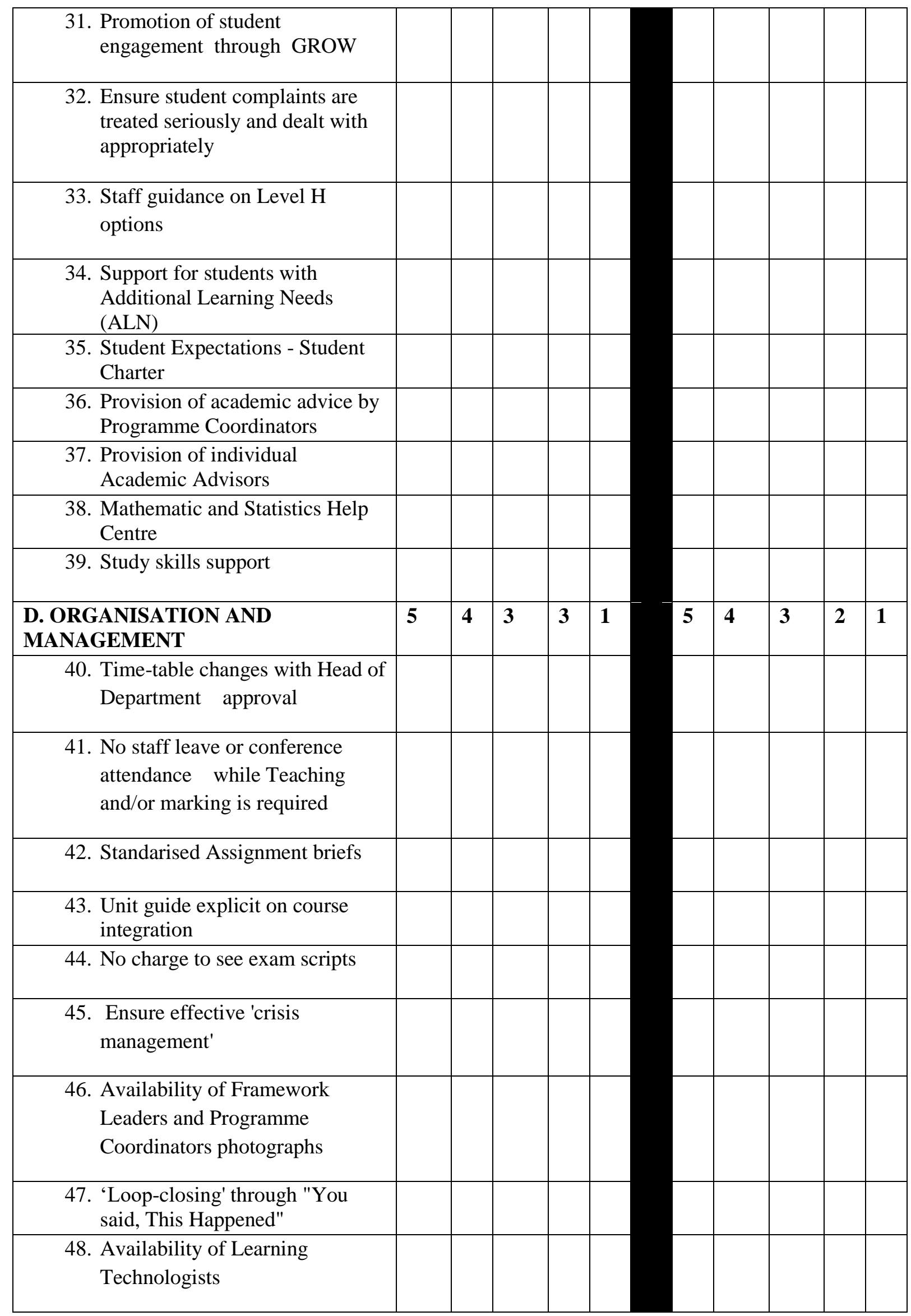




\begin{tabular}{|c|c|c|c|c|c|c|c|c|c|c|}
\hline $\begin{array}{l}\text { 49. Clear communication of any } \\
\text { changes in Management } \\
\text { Structure }\end{array}$ & & & & & & & & & & \\
\hline E. LEARNING RESOURCES & 5 & 4 & 3 & 2 & 1 & 5 & 4 & 3 & 2 & 1 \\
\hline $\begin{array}{l}\text { 50. Accessibility of Core texts by } \\
\text { promoting the use of eBooks }\end{array}$ & & & & & & & & & & \\
\hline $\begin{array}{l}\text { 51. Availability of IT resources and } \\
\text { other facilities }\end{array}$ & & & & & & & & & & \\
\hline F. PERSONAL DEVELOPMENT & 5 & 4 & 3 & 2 & 1 & 5 & 4 & 3 & 2 & 1 \\
\hline $\begin{array}{l}\text { 52. Encourage engagement between } \\
\text { students and employers through } \\
\text { the provision of post- } \\
\text { placement/industry mentors }\end{array}$ & & & & & & & & & & \\
\hline 53. Extend and embed 'Mahara' & & & & & & & & & & \\
\hline $\begin{array}{l}\text { 54. Continue to promote 'Student } \\
\text { Development Award' }\end{array}$ & & & & & & & & & & \\
\hline $\begin{array}{l}\text { 55. Promotion of Academic } \\
\text { Societies }\end{array}$ & & & & & & & & & & \\
\hline $\begin{array}{l}\text { 56. Provision of an Outduction and } \\
\text { Level H support }\end{array}$ & & & & & & & & & & \\
\hline $\begin{array}{l}\text { 57. Enhancement of numeracy skills } \\
\text { and excel training }\end{array}$ & & & & & & & & & & \\
\hline
\end{tabular}


SECTION C (Type all comments under appropriate category i.e. teaching, assessment and feedback, academic support, organisation and management, learning resources and personal development) - Please make sure you identify the comments to a particular individual)

Apart from those initiatives that you have been asked about above, are there any other initiatives that you think the University can introduce to improve your satisfaction for NSS purposes? Please list such initiatives under the following headings:

1. Teaching

2. Assessment and feedback

3. Academic support

4. Organisation and management

5. Learning resources

6. Personal development

Thank you very much for taking time to respond to this questionnaire. The results will help the department to improve student satisfaction for future students. 